\title{
THE EFFICACY OF INSTAGRAM @GURUKUMRD AS THE MEDIA IN IMPROVING STUDENTS READING SKILLS
}

\author{
${ }^{1,2}$ Rizqy Dienillah Fitrina Putri, ${ }^{1}$ Muhamad Sofian Hadi, \& ${ }^{\mathbf{1}}$ Mutiarani \\ ${ }^{1}$ English Language Education, Faculty of Science Education, Universitas Muhammadiyah \\ Jakarta, Indonesia \\ Corresponding Author Email: rizdiefitrinaputri@gmail.com
}

\begin{tabular}{ll}
\hline \hline Article Info & Abstract \\
\hline Article History & Instagram is an online mobile photo and video sharing that can attract students' \\
Received: May 2021 & attention in the learning process. It is also used to interact and share stories to \\
Revised: June 2021 & others directly. Because of this, Instagram is a social media which can be utilized \\
Published: July 2021 & to navigate students to read. This study aims to find out the use of Instagram \\
\hline Keywords & @ gurukumrd to improve students' reading skills. The Instagram @ gurukumrd is \\
Instagram Media; & chosen as the object of this study because it provides students with reading \\
Reading Skill; & activities through stories, comments, and opinions. To reach the aim of this study, \\
& researchers employed qualitative research with Ethnography method. The data \\
& are collected using instruments which are observation sheets and interview \\
& guidelines. There are 37 students involved in this study as respondence. Based on \\
& the research findings, the Instagram @ gurukumrd facilitates students to acquire \\
various vocabulary and grammatical knowledge. In addition, students acquire & competencies on how to gain paragraph ideas, topic sentences, and reading \\
comprehension. Through Instagram, students can remember and recognize \\
difficult words. At the end of this, this media facilitates students to read simple \\
paragraphs quickly. Based on the research findings, this study can conclude that \\
the Instagram @ gurukumrd can facilitate students to enhance students' reading \\
skills.
\end{tabular}

How to cite: Putri, R. D. F., Hadi, M. S., \& Mutiarani. (2021). The efficacy of instagram @ gurukumrd as the media in improving students reading skills, JOLLT Journal of Languages and Language Teaching, 9(3) DOI: https://doi.org/10.33394/jollt.v\%vi\%i.3795

\section{INTRODUCTION}

As a far-off language in Indonesia, English plays an important role in many aspects of life like education, economy, international relationship, and technology. Consequently, the teaching of English becomes a world enterprise. The widespread need for English as a second or foreign language needs substantial pressure on the tutorial resources of many countries (Prabjandee, 2020). Associated with the issues in teaching English, Indonesia introduces English in Elementary school as a local content to offer English to children as early as possible so as to organize them in covering the globalization era (Dukut, 2019; Setyono \& Widodo, 2019). English becomes a compulsory subject in Junior High School, Senior High School, and University (Novita, 2018; Lail, 2019). There are four skills in English: listening, speaking, reading, and writing. The students are expected to possess capacity within the language skills, which overproductive of language use - teaching English not easy. English teachers must not only use the language. However, teachers ought to be ready to facilitate students to learn.

Reading is one of the language skills that ought to be mastered really well by the students because reading is an important factor that influences that one's activity within the communication (Haerazi \& Irawan, 2020; Jang \& Ryoo, 2019). Reading is viewed as a translating ability, that is, deciphering codes into ideas. People think about reading as a big 
activity, in order that people generally state that reading is that the window of the world. People can get knowledge without going anywhere by reading.

Reading skills is that the skills of individuals to read, comprehend and interpret written words on a page of a piece of writing or the other reading. The possession of an honest reading skill will enable the people to be ready to assimilate a written work within a brief period while reading. If people develop reading skills, it is a lifelong activity. While reading at any given time, people are predicted to think critically on the actual topic or subject to know the writer's purpose. Reading skills can only be developed through constant reading. Inculcating reading culture or habit may be a hobby.

The author conducted interviews with English teachers. Based on the results of the interview, many students had difficulties reading, and therefore the students were weak in reading skills. The students' achievement reading score had seen it. The students are required much time to understand the text. They did not use the opportunity to read and learn English text either home. At that time, the students experienced issues in doing the task. Those all made their accomplishment to be lowly and failed in the teaching and learning process. From the teacher's side, how the way of teaching influenced the students' understanding cognizance. Explain too fast, hard explanation and boring technique employed by the teacher jaded the students to read English. The teacher actually utilized the ordinary way in the teaching and learning process.

The teacher just asked the students to read certain text or students' activities text (LKS) and afterward requested that the students do the undertaking following the text. The monotonous process of learning made students discourage to find out. From the students' side, the causes came from students' understanding kind, students' understanding style, students' understanding propensity, and furthermore students' understanding information there have been some causes is that the limited vocabularies, difficulties find the most idea and difficulty to make the conclusion the text. The students did not attempt to discuss the text, and it made them face their own troubles - subsequent, outside from the teacher and students, from the material, and therefore the environment of category. The material used not interesting, like the text contains unfamiliar sentences, which made the students feel hard to find. Then, the unsupporting classroom environment is a negative contribution for students. Besides, that is too monotonous and dreary because no media or method make the students interesting in finding out.

In this era, gadgets are important, and many teenagers or students who use gadgets excessively, even the students like better to play gadgets than study. The students spend of their time on gadgets, sort of a telephone, radio, TV, games, etc. The students use gadgets to play games, watch videos, listen to music, and chat with friends, especially social media because many of us use social media and social media to become part of many people's lives.

Social media is a label for digital technology that permits people to attach, interact, produce, and share the message of the content. (B.K Lewis: 2010). One of the social media that people use is Instagram because Instagram is that the most application that people use which social media is so popular. Many students use Instagram as their social media because Instagram is straightforward to use and has numerous variations and does not cause you to be bored when using it because Instagram is usually updating and improving the appliance.

\section{RESEARCH METHOD}

The author used a Qualitative with Ethnography Method. The ethnography method is an ethnographic study conducted online. Observations can be made in discussions on the mailing list, which are followed by deeper exploration through online chatting with respondents.

\section{Research Design}


Used the Ethnography Method by using Instagram @ gurukumrd as a learning medium to improve students' reading skills. The researcher gives first questions to students before introducing learning media to know students' reading skills. The researcher introduced Instagram @ gurukumrd as a learning media to students and asked students to watch and learn about the video on Instagram @ gurukumrd for two weeks. After that, the researcher observed during the learning process the difficulties and progress of students. When the first week, the researcher gives the second question to know students' reading skills. The researcher gave the last questions to know students' reading skills after watching and learning about the video on Instagram @gurukumrd. And after the learning process is complete, the researcher did interviews with students regarding the given learning media to complement and strengthen the results of this research. And after the learning process is complete, the researcher did interviews with students regarding the given learning media to complement and strengthen the results of this research. This study was conducted at $9^{\text {th }}$ grade from various classes in Yapia Pondok Aren Junior High School, consist of 37 students.

\section{Data Analysis}

In this research, analyze the data is a systematic data processing obtained from observations, interviews, data collection, and record results. In this study the analysis of data in use include: Data Reduction, the process of data reduction is selecting the main things in accordance with the research undertaken. Here the researcher chose the data obtained that focused on the theme of research that is about Instagram @ gurukumrd, reading interests and reading skills. The collected data was compiled, categorizing and categorizing data to make it easier to process and read. Display Data, Information obtained from study subjects will be collected and aggregated in detail. The researcher will explain the results and the researcher clearly describes the data obtained from observations and interviews obtained and will be presented openly, so it looks entirely about use Instagram @gurukumrd, stimulated students to interest in reading to improve students reading skills. Withdrawal Conclusion Once presented clearly, then the final stage of this research is the conclusion. Information obtained from the informants drawn conclusions where the writer look for the meaning of the observations and interviews were obtained. Thus the researcher can know the effectiveness of Instagram@gurukumrd towards ninth-graders school, is that effective to improve students reading skills.

\section{RESEARCH FINDINGS AND DISCUSSION Research Findings}

Before the researcher gives the Instagram @gurukumrd learning media on the WhatsApp group, the researcher gives 15 questions, and after the questions were given, then the answer sheets were written by the students themselves which were then photographed and sent via personal chat on WhatsApp to know student ability limits and can measure students' reading ability before students use the learning media.

The researcher provides the Instagram @ gurukumrd link for the learning method, and the researcher also explains about Instagram @ gurukumrd through WhatsApp group. After that the researcher gives two weeks for students to learn on their own using these learning media. During the two weeks process they learned to use the media. The researcher gave two practice questions every week, each of which amounted to 15 questions, and the total questions given as a whole in this study were 45 questions to monitor the students in the learning process. The researcher does not use Google Drive because almost all of the students prefer to write the answer sheet, which is then photographed and sent via personal chat on WhatsApp. 
The students' answer sheet results about the first questions that were given before the researcher gave the media and learning method were that many students did not understand and still wrong in answering the questions and the lack of vocabulary that students knew. The students' answer sheet results about the second question that were given when the researcher had provided the media and learning method and the students had studied for one week, the students experienced an increase, it could be seen from the results answer sheets that were collected. The results of the students answer sheet about the last question that was given when the researcher had provided the media and learning method and the students had studied for two weeks, the vocabulary of the students' increases and students are more interested in learning to read English questions because the media and methods provided are very unique and interesting. The students have never studied English using Instagram media before, so the students are very interesting and exciting in following the learning process using Instagram.

Based on the interview, the teacher still used ordinary ways in almost everyday teaching and learning process. The teacher just asked the students to read certain text within the book or students' exercises book (LKS), then asked the students to try to do the task following the text. I found that the students were in reading just read certain text within the book or students' exercises book (LKS), then the students only learn when the students get assignments from the teacher. Almost all of the scholars in ninth grade got the issues. There is some causes the limited vocabularies, and difficulties find the most idea, and difficulties in making a conclusion of the text. The students did not attempt to discuss the text and it made them face their own difficulties. Some students are lack reading in English because the students do not read English texts outside of school hours. Students only read during in class and when they get assignments, so that it makes the students lack of understanding in reading English. All of the students' interest in reading in English but sometimes the method that the teacher teaching is not interesting so that it makes students less interested in learning. Students need learning methods that attract students in learning and are easy to understand.

\section{Discussion}

This stusy is orieneted to investigate the use of Instagram as social media to improve students' reading skills. The Instagram media applied is @gurukumrd media. The Instagram media facilitate students with the story, comment, and opinion features. The features are utilized by English teachers to provide their reading materials for students. Students with various reading texts can spend their time to read texts provided by teachers. It is in line with Haerazi et al. (2020) who state that various reading texts can guide students to acquire a lot vocabularies. In addition, McLain (2019) argues that technologies such as Instagram, facebook, Twitter, and YouTube have great potential to develop learning activities and make stronger the teaching-learning practices.

Based on the research findings, students are able to increase reading skills using Instagram media. Students are asked to read texts. Then, they post their comprehension of the text. Students are also asked to discuss the content of the text being read. Some vocabularies that they do not understand are listed, and they open dictionary to find the meaning of those. These learning activities are able to acquire new vocabulary and reading comprehension (Arndt \& Woore, 2018; Haerazi et al., 2020). Besides, students are involved in searching videos relating to the reading topic. Teachers provided them with various YouTube videos that have the same topic. The use of video can guide them to attain more comprehension of the reading topics (Serder-Tuluce \& Cecen, 2018; Bardakci, 2019). Therefore, this study indicated the students' reading skills increased.

It was seen from the results of the students answer sheets, then the students' vocabulary increases and students are more interested in learning to read English because the media and methods provided are very unique and interesting. It is in accordance with Nagaletchinee 
(2015) who argues that the use of various media can facilitate students to learn and adjust their learning activities. Students are more interested because students have never previously received media and learning methods using social media, especially Instagram, making students want to know more about the media and learning methods that the writer provides. Some of students even took the initiative to contact the researcher directly to ask about learning English using social media and other media that can be used to learn English. Students need new media and methods to learn English, this indicates that students have an increased enthusiasm and interest in learning English.

Based on the interviews with researchers, some students still do not understand the materials presented by the teacher because the teacher only explains and then asks students to do tasks or exercises. No one variation in the learning process makes the learning process monotonous and that it makes students feels bored and do not excited about the learning process. Students need media and learning methods that are new and varied so that students do not get bored and can improve students' learning ability to read, especially class of ninth grade students who have a spirit that is still up and down to learn, therefore the importance of variety, new media and learning methods and interesting to attract students' reading interest.

\section{CONCLUSION}

Based on the research, it can be concluded that using Instagram as the media can improve students' reading skills in English. The students need media and learning methods that are not monotonous and varied and easy to understand so that students can be interested and can increase their interest in learning to read in English because if students learn too monotonously and do not get anything new, it can make students lose their enthusiasm for learning because students are ninth grade students so that there needs to be a lot of variation in learning to increase students' enthusiasm for learning.

The important of the teacher's role to have good and structured learning methods so that students can learn well and they do not feel bored with the material being taught and enthusiast in learning. The thing that must be considered by the teacher when teaching is the condition of students, if students experience boredom in learning, it is difficult for students to understand the lessons conveyed. It is important for teachers to pay attention to the conditions of all their students.

\section{REFERENCES}

Arndt, H. L., \& Woore, R. (2018). Vocabulary learning from watching YouTube videos and reading blog posts. Language Learning and Technology, 22(3), 124-142.

Ambarini, R.., Sumardiyani, L., \& Wardoyo, S. L. (2018). PACA (Predicting And Confirming Activity) Reading Strategies to Promote Students' Teaching Strategy in TEFL 1 Class. Celt: A Journal of Culture, English Language Teaching \& Literature, 18 (1), 42.

Anwar., I. W., \& Wahid., J. H., 2021). Learners' Perception on Online Learning Implementation During Covid-19 Pandemic. International Journal of Language Teaching and Education, 9(2), 126-128.

Bardakci, S. (2019). Exploring high school students' educational use of youtube. International Review of Research in Open and Distance Learning, 20(2), 260-278. https://doi.org/10.19173/irrodl.v20i2.4074

Brown. (2000). Teaching is Guiding and Facilitating Learning. San Francisco: SCRIBD.

B.K, Lewis. (2010). Social media may be a label for digital technology. Wuhan: Research Project Publishing. 
Dukut, E. M. (2019). Popularizing Indonesian scenes through picture books and digital animation software: a World Englishes teaching idea. Asian Englishes, 21(2), 142-157. https://doi.org/10.1080/13488678.2018.1459071

Haerazi, \& Irawan, L. A. (2020). The effectiveness of ECOLA technique to improve reading comprehension in relation to motivation and self-efficacy. International Journal of Emerging Technologies in Learning, 15(1), 61-76. https://doi.org/10.3991/ijet.v15i01.11495

Haerazi, H., Utama, I. M. P., \& Hidayatullah, H. (2020). Mobile Applications to Improve English Writing Skills Viewed from Critical Thinking Ability for Pre-Service Teachers. International Journal of Interactive Mobile Technologies (IJIM), 14(07), 58. https://doi.org/10.3991/ijim.v14i07.11900

Hartatik, S. F., \& Lestari, H. D. (2016). Reading experience non-native English speaking students majoring in English language teaching. JEES (Journal of English Educators Society), 1 (October), 105-114.

Indrianti, F. (2019). The Effectiveness of Using Graphic Organizer in Students' Reading Comprehension. Thesis. Purwokerto: English Department of Education, Faculty of English Training and Education Faculty, Muhammadiyah University of Purwokerto.

Jang, B. G., \& Ryoo, J. H. (2019). Multiple dimensions of adolescents' reading attitudes and their relationship with reading comprehension. Reading and Writing, 32(7), 1769-1793. https://doi.org/10.1007/s11145-018-9926-6

Juliet, \& Anselm. (2014). Qualitative Research. San Francisco: Basics of Qualitative Research: Techniques and Procedures for Developing Grounded Theory 4th Edition Paperback.

Kozinets, R. V. (2015). Netnography. Research Gate. California: University of Southern California, 2-8.

Lail, H. (2019). Answering Reading Texts on English Tryout Test Based on the 12Th Grade Students' Strategies at SMA Negeri1 Kuripan Lombok Barat. JOLLT Journal of Languages and Language Teaching, 7(1), 3. https://doi.org/10.33394/jollt.v7i1.1434

McLain, T. R. (2019). Social media treasure hunt - Practical lessons using twitter in the English classroom. Teaching English with Technology, 19(2), 88-100.

Novita, D. (2018). Syndicate Learning: an Alternative Approach for Teaching Extensive Reading. Journal of Languages and Language Teaching, 6(1), 27. https://doi.org/10.33394/jollt.v6i1.810

Nagaletchimee, A. (Universiti S. M. (2015). Using Whatsapp To Extend Learning. Teaching English with Technology, 19(1), 3-20.

Prabjandee, D. (2020). Teacher professional development to implement Global Englishes language teaching. Asian Englishes, 22(1), 52-67. https://doi.org/10.1080/13488678.2019.1624931

Serdar-Tülüce, H., \& Çeçen, S. (2018). The use of video in microteaching: affordances and constraints. ELT Journal, 72(1), 73-82. https://doi.org/10.1093/elt/ccx028

Setyono, B., \& Widodo, H. P. (2019). The representation of multicultural values in the Indonesian Ministry of Education and Culture-Endorsed EFL textbook: a critical discourse analysis. Intercultural Education, 30(4), 383-397. https://doi.org/10.1080/14675986.2019.1548102

Troyer, M., Kim, J. S., Hale, E., Wantchekon, K. A., \& Armstrong, C. (2019).. Relations among intrinsic and extrinsic reading motivation, reading amount, and comprehension: a conceptual replication. Reading And Writing, 32 (5), 1197-1218.

Wikipedia. (2020)., from http://en.wikipedia.org/wiki/Instagram

Instagram (2021)., from http://instagram.com/gurukumrd 